\title{
Effects of Titanium Dioxide Nanoparticles Exposure on Human Health-a Review
}

\author{
Ewa Baranowska-Wójcik ${ }^{1} \cdot$ Dominik Szwajgier $^{1} \cdot$ Patryk Oleszczuk $^{2} \cdot$ Anna Winiarska-Mieczan $^{3}$
}

Received: 23 January 2019 / Accepted: 19 March 2019/Published online: 13 April 2019

(C) The Author(s) 2019

\begin{abstract}
Recently, an increased interest in nanotechnology applications can be observed in various fields (medicine, materials science, pharmacy, environmental protection, agriculture etc.). Due to an increasing scope of applications, the exposure of humans to nanoparticles (NPs) is inevitable. A number of studies revealed that after inhalation or oral exposure, NPs accumulate in, among other places, the lungs, alimentary tract, liver, heart, spleen, kidneys and cardiac muscle. In addition, they disturb glucose and lipid homeostasis in mice and rats. In a wide group of nanoparticles currently used on an industrial scale, titanium dioxide nanoparticles - $\mathrm{TiO}_{2} \mathrm{NPs}$ - are particularly popular. Due to their white colour, $\mathrm{TiO}_{2} \mathrm{NPs}$ are commonly used as a food additive (E 171). The possible risk to health after consuming food containing nanoparticles has been poorly explored but it is supposed that the toxicity of nanoparticles depends on their size, morphology, rate of migration and amount consumed. Scientific databases inform that $\mathrm{TiO}_{2} \mathrm{NPs}$ can induce inflammation due to oxidative stress. They can also have a genotoxic effect leading to, among others, apoptosis or chromosomal instability. This paper gives a review of previous studies concerning the effects of exposure to $\mathrm{TiO}_{2}$ NPs on a living organism (human, animal). This information is necessary in order to demonstrate potential toxicity of inorganic nanoparticles on human health.
\end{abstract}

Keywords $\mathrm{TiO}_{2} \cdot$ Nanoparticles $\cdot$ Health $\cdot$ Food $\cdot$ Toxicity

\section{Introduction}

Recently, nanotechnology has been a subject of great interest, offering considerable advantages in many areas. Titanium dioxide $\left(\mathrm{TiO}_{2} \mathrm{NPs}\right)$ is among the most often used nanoparticles. The particle size depends on its application, including ultrafine particles $<100 \mathrm{~nm}$, and fine particles 0.1 to ca. $3 \mu \mathrm{m}$ [1]. It occurs in three different variants: as rutile, anatase and, more rarely, brookite [2, 3] (Fig. 1) [4]. With regard to its increased photocatalytic activity $[3,5]$, anatase in comparison to rutile

Ewa Baranowska-Wójcik

ewa.baranowska@up.lublin.pl

1 Department of Biotechnology, Microbiology and Human Nutrition, University of Life Sciences in Lublin, Skromna 8, 20-704 Lublin, Poland

2 Department of Environmental Chemistry, Maria Curie-Skłodowska University in Lublin, Pl. M. Curie-Skłodowskiej 3, 20-031 Lublin, Poland

3 Department of Bromatology and Food Physiology, University of Life Sciences in Lublin, Akademicka 13, 20-950 Lublin, Poland and brookite has a higher number of industrial applications; however, it is the most toxic form [6].

\section{Occurrence of $\mathrm{TiO}_{2} \mathrm{NPs}$}

$\mathrm{TiO}_{2} \mathrm{NPs}$ is used in many areas of life, such as environmental protection and building engineering, medicine, agriculture and the food and cosmetic industry [4] (Fig. 2) [7]. With regard to its catalytic properties, $\mathrm{TiO}_{2} \mathrm{NPs}$ are a component of self-cleaning roof tiles, windows, they are used in water and sewage treatment, gas combustion, as an antibacterial material for decontamination, as well as a catalyst in organic synthesis $[2,8]$. Their biomedical applications include pharmaceuticals and medical devices [2]. In the agriculture industry, they are used in the production of fertilisers and pesticides which can significantly affect soil fertility, growth of plants and crop yield $[9,10] . \mathrm{TiO}_{2} \mathrm{NPs}$ have a wide range of applications in the food industry (E171) [11, 12]; they are used in the processing and packing of food for the purposes of product improvement. They are also used in the cosmetics industry, pharmaceuticals and toothpastes [13-15]. They have a wide-range 


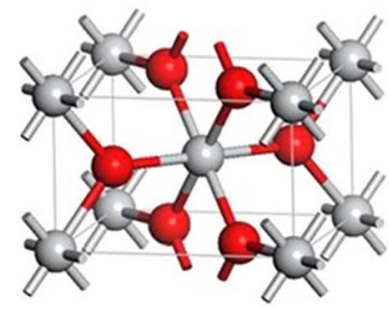

rutile

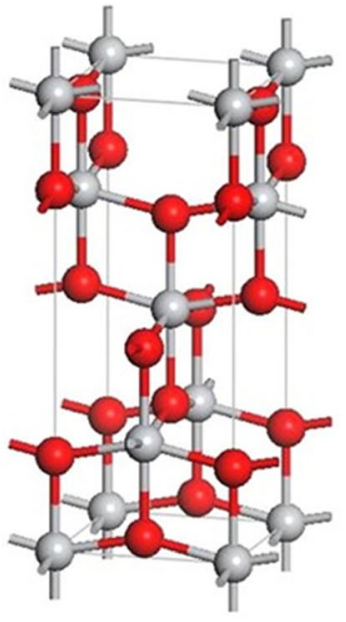

anatase

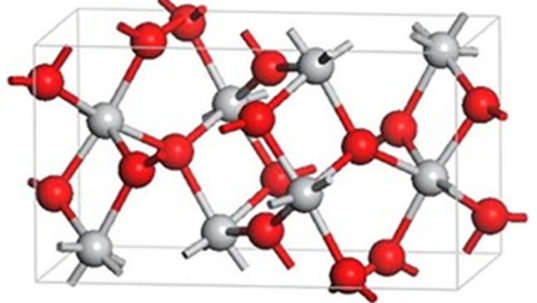

brookite

Fig. 1 Tetragonal structures of crystalline forms of rutile, anatase and brookite $\mathrm{TiO}_{2} \mathrm{NPs}$ (spheres: red $-0_{2}$, grey—Ti). Based on Samat et al. [4]

antibacterial effect extending the shelf life of foodstuffs [16, 17].

With regard to the fact that $\mathrm{TiO}_{2} \mathrm{NPs}$ are used widely and commonly in many areas of industry, the risk of exposure increases; hence, their potential effect on the human body should be explored in more detail.

\section{$\mathrm{TiO}_{2}$ NPs in Foodstuffs}

In recent years, the effect of nanoparticles on human health has given rise to serious controversies. According to the Nanotechnology Consumer Product Inventory (CPI), from March 2015, the global market offered 1814 products based on nanotechnology, including 117 in the "food and beverage" category $[18,19]$. In the USA, $\mathrm{TiO}_{2} \mathrm{NPs}$ can be used in food if its content does not exceed $1 \%$ of the total weight of the product containing $\mathrm{nTiO}_{2}$ [20-22]. In Europe, the at quantum satis principle is in force, which means it can be used in amounts not exceeding the intended target level [23, 24].

\section{$\mathrm{TiO}_{2}$ NPs as a Food Additive}

TiO2 NPs are added to many foodstuffs, including cheeses and sauces, skimmed milk, ice cream and confectionery products, e.g. as coating on sweets and chewing gum [23, 25-27]. Its content in sweets, and in particular in candy, chewing gum, chocolate and white-coated products, compared to other products, is very high, reaching $2.5 \mathrm{mg} \mathrm{Ti} / \mathrm{g}$ of food [24, 25]. It is estimated that a child can consume even 2-4 times more $\mathrm{TiO}_{2}$ NPs per $1 \mathrm{~kg}$ of body weight (bw) a day than an adult person. cosmetics $10 \%$

pplication of $\mathrm{TiO}_{2} \mathrm{NPs}$ (\%) in industry. Based on Hong et.al [7] medicine, food

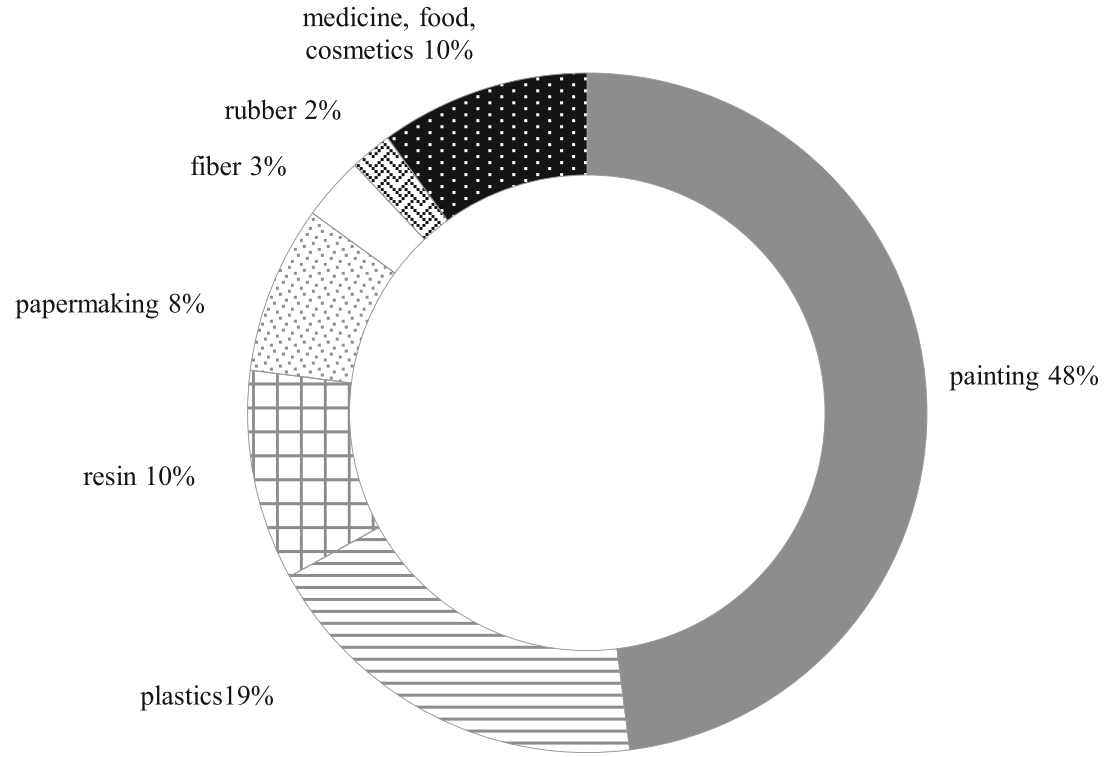


In Great Britain, children under the age of 10 consume about 2-3 $\mathrm{mg} \mathrm{TiO}_{2} / \mathrm{kg} \mathrm{BW} /$ day, while adults consume about $1 \mathrm{mg}$ $\mathrm{TiO}_{2} / \mathrm{kg}$ bw/day [6].

\section{Safety of $\mathrm{TiO}_{2}$ NPs in Foodstuffs}

The wide applications of $\mathrm{TiO}_{2} \mathrm{NPs}$ in the food industry give rise to many controversies regarding safety. The International Agency for Research on Cancer (IARC) classified the $\mathrm{TiO}_{2}$ NPs pigment as a potential carcinogenic factor from group $2 \mathrm{~B}$ (probably carcinogenic to humans) based on mechanisms and tests involving animals regarding exposure by inhalation [28-30]. The European Food Safety Authority (EFSA) in its latest study on the safety of E171 (titanium dioxide) in 2016 found that data concerning values and exposure of humans to $\mathrm{TiO}_{2}$ NPs in food do not raise concerns [24]. However, with regard to the insufficiency of research data, the admissible daily intake of $\mathrm{TiO}_{2}$ NPs was not determined. Based on the results of tests involving animals, a safety margin of $2.25 \mathrm{mg}$ $\mathrm{TiO}_{2}$ NPs/kg bw/day was established [24].

\section{Ways of Exposure and Accumulation of $\mathrm{TiO}_{2}$ NPs in Human/Animal Body}

The effect of $\mathrm{TiO}_{2}$ NPs on the human body has been explored for many years. Both its exposure and toxicity to a human body/animal body has been widely investigated and discussed. The crystalline structure, particle size and coating can affect the surface charge, sedimentation, aggregation and thus toxicity of $\mathrm{TiO}_{2}$ NPs [31-34].

The previous in vitro and in vivo tests confirm the toxic effects of $\mathrm{TiO}_{2}$ NPs on human body such as altered cell cycle, constriction of nuclear membranes and apoptosis [35-38]. Studies also showed that $\mathrm{TiO}_{2}$ NPs can cause DNA damage $[32,39,40]$ and interact with the epithelium of the small intestine responsible for absorption of nutrients. After exposure to $\mathrm{TiO}_{2}$ NPs by various ways, mainly by inhalation, injection, skin contact and absorption in the alimentary tract, $\mathrm{TiO}_{2}$ NPs can be found in different internal organs. In vivo tests revealed that after inhalation or oral exposure, $\mathrm{TiO}_{2} \mathrm{NPs}$ accumulate in, among other places, the lungs, alimentary tract, liver, heart, spleen, kidneys and cardiac muscle. In addition, they disturb glucose and lipid homeostasis in mice and rats [41-43, 34]. Age can also be a factor playing a significant role in the harmful effect of $\mathrm{TiO}_{2}$ NPs. As indicated by the results of tests on young and adult rats [44], different age groups can require different biomarkers for detecting and monitoring oral toxicity of nanoparticles. In young rats, liver swelling was observed, along with cardiac injuries and non-allergic activation of mast cells in gastric tissue. On the other hand, adult animals showed insignificant liver and renal damage as well as reduced intestinal permeability and molybdenum content following exposure to $\mathrm{TiO}_{2}$ NPs. Wang et al. [45] demonstrated that the size of nanoparticles can affect both toxicity and accumulation of $\mathrm{TiO} 2 \mathrm{NPs}$ in different organs. Those authors, after a one-time oral administration of $\mathrm{TiO}_{2} \mathrm{NPs}$ to mice of different size, demonstrated that larger particles $(80 \mathrm{~nm})$ are mainly accumulated in the liver, whereas smaller particles $(25 \mathrm{~nm})$ can be found in the spleen and, to a lesser extent, in the kidneys and lungs.

\section{Biodistribution and Absorption of $\mathrm{TiO}_{2} \mathrm{NPs}$ in Human/Animal Body}

All nanomaterials can differ considerably in composition, charge, morphology, specific surface area and state of matter, which has an influence on what happens to them in the alimentary tract and potential toxicity [46]. Food differs greatly in terms of its composition, appearance, structure and physical properties, which can lead to perceptible changes in the properties of nanoparticles, including their release, transport, solubility, state of matter and absorption. The nature and type of food containing inorganic nanoparticles can affect what happens to them in the alimentary tract $[46,47]$. The content of water can affect the release of nanoparticles from the food matrix, whereas processing of food before it is swallowed can significantly alter the structure and properties of proteins [47, 48]. NPs, before they are absorbed in the human body, must pass through the gastrointestinal tract (GIT) regions (Fig. 2), which can alter their properties and change their potential toxicity [47]. The degree of intake and absorption of $\mathrm{TiO}_{2}$ NPs from the GIT into the blood circulation system can depend on many factors, i.e. species, type of particles/ nanoparticles, their size, dispersability or particle charging $[49,50]$.

The current data is inconsistent and most of it indicates that when swallowed, most particles are not absorbed into the blood circulation system but are excreted with the GIT [49]. The results of recent studies showed that $\mathrm{TiO}_{2} \mathrm{NPs}$ were scarcely captured from the GIT and transferred into systemic circulation in rats and humans [51-53]. Studies concerning toxicity after oral administration to rats show a low level of toxicity at NOAEL $>1000 \mathrm{mg} / \mathrm{kg}$ bw/24 h (NOAEL-no observable adverse effect level) [49]. Cho et al. [53] demonstrated that the concentration of titanium in blood, when $\mathrm{TiO}_{2}$ NPs were administered to rats as particles every day (up to $1042 \mathrm{mg} / \mathrm{kg}$ bw/day), was not significantly higher than in the control group. Similarly, MacNicoll et al. [54] in their studies involving rats showed that a dose of $5 \mathrm{mg} \mathrm{TiO}{ }_{2} \mathrm{NPs} / \mathrm{kg}$ body weight did not lead to considerable capturing of $\mathrm{TiO}_{2} \mathrm{NPs}$ (measured as titanium) from the GIT into the blood, urine or different internal organs. Also, studies involving humans found that the absorption from the GIT into blood and urine 
was scarce [51]. It was demonstrated that both after administration of a single dose to volunteers ( $5 \mathrm{mg} / \mathrm{kg}$ bw/day) and of $\mathrm{TiO}_{2}$ NPs with different particle sizes, $15 \mathrm{~nm}$ (nanoshell), $100 \mathrm{~nm}$ (nanoshell) and $<5000 \mathrm{~nm}$ (pigments), $\mathrm{TiO}_{2} \mathrm{NPs}$ had no impact on increased absorption of titanium depending on the particle size [51].

\section{Alimentary Tract}

Studies have shown that nanoparticles can disturb digestion and absorption of food components, which can lead to deficiencies of macro- and microelements in the body [47]. Chen et al. [55] studied the toxicity of $\mathrm{TiO}_{2} \mathrm{NPs}$ in mice in vivo. Different doses $(0,324,648,972,1296,1944,2592 \mathrm{mg} / \mathrm{kg}$ ) were injected into their mouth at different time intervals $(24 \mathrm{~h}$, $48 \mathrm{~h}, 7$ days and 14 days). Mice showed strong symptoms of toxicity (loss of appetite, passive behaviour, trembling and lethargy). The highest accumulation of $\mathrm{TiO}_{2} \mathrm{NPs}$ was found in the spleen that also sustained damage. Other observations included necrosis of liver cells and apoptosis, liver fibrosis and swelling of renal glomeruli. $\mathrm{TiO}_{2} \mathrm{NPs}$ were also deposited in the lungs where blood clots were found that could have resulted from blockage of blood vessels. Duan et al. [56] demonstrated weight loss in mice after intragastric administration of $\mathrm{TiO}_{2}$ NPs anatase in doses of 125 and $250 \mathrm{mg} / \mathrm{kg}$. This should be explained by the reduced number of intestinal villi and the resulting loss of surface of the small intestine capable of absorbing nutrients, which consequently leads to malnutrition and weight loss. Amedollia et al. [57] in their studies also showed that after oral exposure of rats to a dose of $2 \mathrm{mg} / \mathrm{kg}$ body weight, $\mathrm{TiO}_{2} \mathrm{NPs}$ are capable of penetrating the intestinal mucosa. Brun et al. [58] argue that it is likely that $\mathrm{TiO}_{2}$ NPs would be translocated both through the ileac epithelium and through Peyer's patches, which would lead to damage and most likely chronic failure of the intestinal epithelium. Nogueira et al. [59] found an inflammation in the small intestine of mice after they were administered $\mathrm{TiO}_{2} \mathrm{NPs}(66 \mathrm{~nm})$ by oral gavage in the dose of $100 \mathrm{mg} / \mathrm{kg}$ over 10 days.

The results of the abovementioned in vivo tests confirmed the results of in vitro studies on human intestine cell cultures. The authors [60] came to similar conclusions. Their studies on Caco-2/HT29-MTX cells showed that exposure to $\mathrm{TiO}_{2} \mathrm{NPs}$ had a considerable impact on the transportation of nutrients, that is, $\mathrm{Fe}$ and $\mathrm{Zn}$, capturing of fatty acids and IAP activity (inhibitor of apoptosis protein). They found a decrease in the number of microvilli resulting in a reduction of the surface area available for absorption of nutrients. Faust et al. [21], in their in vitro studies of the human intestine model, showed that after exposure to $\mathrm{TiO}_{2} \mathrm{NPs}$, the villi in the small intestine were destroyed. They also found that about $42 \%$ of intestinal microvilli were lost when $350 \mathrm{ng}$ of $\mathrm{TiO}_{2} \mathrm{NPs}$ were added per $1 \mathrm{~cm}^{2}$ of the medium.
The present studies provide evidence that $\mathrm{TiO}_{2} \mathrm{NPs}$ have both a positive and negative effect on the quality of intestinal villi, which seems to be dependent on the dose and on the age of the animals. In young animals, the permeability of the intestinal wall is probably higher, and thus the rate of absorption and bioavailability is increased, which leads to increased exposure to $\mathrm{TiO}_{2} \mathrm{NPs}$ [61].

Wang et al. [62], after intragastric administration of $\mathrm{TiO}_{2}$ NPs to mice over 30 days in three doses $(5,50$ and $150 \mathrm{mg} / \mathrm{kg}$ bw), observed insignificant damage to the cells of the spleen (denser and larger lymph follicles in splenic tissue) in animals exposed to the lowest dose, which was not the case with higher concentrations. $\mathrm{TiO}_{2} \mathrm{NPs}$ caused a significant increase in the accumulation of reactive oxygen species in the spleen of mice due to lipid peroxidation. Mohamed [63] administered 5, 50 and $500 \mathrm{mg} \mathrm{TiO}{ }_{2} \mathrm{NPs} / \mathrm{kg}$ bw to mice orally and found that, even when the dose was low, $\mathrm{TiO}_{2} \mathrm{NPs}$ were permanently accumulated in mice, which led to inflammation, apoptosis and oxidative stress, and consequently induced chronic gastritis.

In most of the existing studies, liver failure was observed in mice and rats exposed to $\mathrm{TiO} 2 \mathrm{NPs}$. Bu et al. [64], after oral administration of $\mathrm{TiO}_{2} \mathrm{NPs}$ to rats, observed liver and heart damage as the consequences of disturbances in energy and amino acid metabolism and in intestinal microflora. Duan et al. [56] came to similar conclusions. They observed an increase in liver ratios and histopathological changes in the liver after oral administration of $\mathrm{TiO}_{2} \mathrm{NPs}(5 \mathrm{~nm})$ to mice at $62.5,125$ and $250 \mathrm{mg} / \mathrm{kg}$ bw over 30 days.

In three publications, the researchers [Kreyling et al. 65-67] investigated biokinetics and translocation of $\mathrm{TiO}_{2}$ NPs administered via three classical ways (intravenous injection $(40-400 \mathrm{mg} / \mathrm{kg})$, oral administration $(30-80 \mathrm{mg} / \mathrm{kg}$ ) and injection into the trachea $(40-240 \mathrm{mg} / \mathrm{kg})$ in identical laboratory conditions. Female rats were administered single doses of anatase nanoparticles ( $\left.\mathrm{TiO}_{2} \mathrm{NPs}\right) 48 \mathrm{~V}$ isotope labelled to ensure precise tracking of translocation kinetics and total biodistribution of $48 \mathrm{~V}-\mathrm{nTiO}_{2} \mathrm{NPs}$ in different tissues over 28 test days. It was found that a single dose administered orally was $99.7 \%$ excreted with faeces whereas $0.3 \%$ remained in the body for at least 7 days and continued to accumulate in the liver and spleen according to previous studies $[68,44,45]$. Other results of tests on mice show that oral administration of $5 \mathrm{mg} \mathrm{TiO}{ }_{2} \mathrm{NPs} / \mathrm{kg}$ bw (5 days, 10 weeks) can contribute to intensification of an existing intestinal cancer (colon cancer) [69].

Literature also recounts cases where $\mathrm{TiO}_{2} \mathrm{NPs}_{\text {s had no toxic }}$ effect. In the 90-day-long study on oral toxicity, male and female rats were exposed to $\mathrm{TiO}_{2} \mathrm{NPs}$ via gastric tube at 0 , 100,300 and $1000 \mathrm{mg} / \mathrm{kg}$ bw/day. No deaths were recorded in connection with $\mathrm{TiO}_{2}$ NPs and no clinical, ophthalmological or neurobehavioural changes were observed due to exposure to $\mathrm{TiO}_{2} \mathrm{NPs}$. In addition, no adverse effects on body weight 
were recorded. The largest examined dose, i.e. $1000 \mathrm{mg} / \mathrm{kg}$ BW/day, did not cause any changes in male and female rats [49].

Similarly, Warheit et al. [70] did not find any changes in the body weight of rats after administration of $5 \mathrm{~g} \mathrm{TiO}_{2} \mathrm{NPs} / \mathrm{kg}$ BW. Other authors [57] studying HT-29 cell cultures did not find $\mathrm{TiO}_{2} \mathrm{NPs}$ to have a cytotoxic effect at different concentrations $\left(1-20 \mathrm{mg} / \mathrm{cm}^{2}\right)$ after 6,24 and $48 \mathrm{~h}$ exposure, either. Table 1 summarises the effect of $\mathrm{TiO}_{2} \mathrm{NPs}$ exposure.

\section{Cardiovascular System}

Different ways of exposure to nanoparticles can have various influences on the cardiovascular system. The influence depends on the amounts, dose of exposure, mechanisms and transfer routes, duration of exposure and the target organ [20].

Some studies showed that $\mathrm{TiO}_{2} \mathrm{NPs}$ could be toxic and have a negative effect on the cardiovascular system. The inflammatory response triggered by $\mathrm{TiO}_{2} \mathrm{NPs}$ is deemed one of the main causes for cardiovascular system malfunction. Increased expression of inflammatory cytokines such as TNF- $\alpha$, INF-g and IL- 8 in blood after intake of $\mathrm{TiO}_{2}$ NPs was observed by Gui et al. [71] and Trouiller et al. [72]. Chen et al. [20], in their in vivo tests on rats, set forth a hypothesis that heart damage and inflammatory response could be possible mechanisms of adverse cardiovascular activity triggered by $\mathrm{TiO}_{2} \mathrm{NPs}$. They demonstrated that a low dose of $\mathrm{TiO}_{2} \mathrm{NPs}$ could lead to potential undesirable cardiovascular effects after 30 or 90 days of oral exposure. After 90 days of intravenous administration of $\mathrm{TiO}_{2} \mathrm{NPs}(0,2,10,50 \mathrm{mg} / \mathrm{kg})$, those authors observed heart arrhythmia manifested in reduced activity of lactate dehydrogenasis (LDH), $\alpha$-hydroxybutyrate dehydrogenase (alpha-HBDH) and creatine kinase (CK). After shorter exposure to $\mathrm{TiO}_{2} \mathrm{NPs}$ (30 days), changes in heart rate (HR) and blood pressure (BP) could be noted. Savi et al. [73] discovered that intra-breath in vivo administration of the saline solution containing $\mathrm{TiO}_{2} \mathrm{NPs}(2 \mathrm{mg} / \mathrm{kg})$ increased the rate of cardiac conduction, which results in increased likelihood of developing arrhythmia. Kan et al. [74], in their studies, demonstrated that after inhalation of ultrafine titanium dioxide $\left(\mathrm{UFTiO}_{2}\right)$, the heart rate considerably increased and the average diastolic blood pressure was higher in response to isoproterenol.

Wang [45] evaluated the toxicity of $\mathrm{TiO}_{2} \mathrm{NPs}$ (25 and $80 \mathrm{~nm}$ ) in adult mice in comparison to fine $\mathrm{TiO}_{2} \mathrm{NPs}$ $(155 \mathrm{~nm})$. A fixed dose of $5 \mathrm{~g} / \mathrm{kg}$ bw was determined according to the procedure designed by the Organisation for Economic Cooperation and Development (OECD). Changes were identified in the following biochemical parameters in

Table 1 The effect of exposure to $\mathrm{NPsTiO}_{2}$ on the alimentary tract

\begin{tabular}{|c|c|c|c|c|c|}
\hline Model & Type $\mathrm{NPsTiO}_{2}$ & Dose & Exposure time & Effect & References \\
\hline Mice & Anatase- $\mathrm{TiO}_{2}$ & $\begin{array}{c}0.324,648,972,1296 \\
1944,2592 \mathrm{mg} / \mathrm{kg}\end{array}$ & $\begin{array}{l}24 \mathrm{~h}, 48 \mathrm{~h}, 7 \\
14 \text { days }\end{array}$ & $\begin{array}{l}\text { Spleen damage, necrosis of liver cells } \\
\text { and apoptosis, liver fibrosis, swelling } \\
\text { of renal glomeruli }\end{array}$ & {$[55]$} \\
\hline Rats & Anatase- $\mathrm{TiO}_{2}$ & $2 \mathrm{mg} / \mathrm{kg}$ & 5 days & & {$[57]$} \\
\hline Caco-2/HT29-MTX & Unknown & 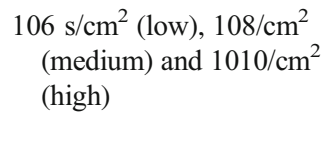 & $4 \mathrm{~h}, 5$ days & $\begin{array}{l}\text { Decrease in the number of microvilli } \\
\text { resulting in a reduction of the surface } \\
\text { area available for absorbtion of } \\
\text { nutrients }\end{array}$ & {$[60]$} \\
\hline Caco-2BBe1 & $\begin{array}{l}\text { Food grade } \\
\mathrm{TiO}_{2} \text {, isolated from } \\
\quad \text { candy }\end{array}$ & $\begin{array}{l}350 \mathrm{ng} \mathrm{TiO}{ }_{2} \mathrm{NPs} / \mathrm{cm}^{2} \\
\text { medium }\end{array}$ & 19-21 days & & {$[21]$} \\
\hline Mice & Anatase $\mathrm{TiO}_{2}$ & 5,50 and $150 \mathrm{mg} / \mathrm{kg}$ & 30 days & $\begin{array}{l}\text { Insignificant damage to the cells of the } \\
\text { spleen in animals exposed to the } \\
\text { lowest dose. Significant increase in } \\
\text { the accumulation of reactive oxygen } \\
\text { species in the spleen of mice due to } \\
\text { lipid peroxidation }\end{array}$ & {$[62]$} \\
\hline Mice & $\begin{array}{l}\text { Mixture of rutile and } \\
\text { anatase }\end{array}$ & 5,50 and $500 \mathrm{mg} / \mathrm{kg}$ & $\begin{array}{c}24 \mathrm{~h}, 7 \text { and } \\
14 \text { days }\end{array}$ & $\begin{array}{l}\text { Apoptosis, oxidative stress, chronic } \\
\text { gastritis }\end{array}$ & {$[63]$} \\
\hline Rats & Unknown & $0.16,0.4$ and $1 \mathrm{~g} / \mathrm{kg}$ & 14 days & $\begin{array}{l}\text { Liver and heart damage as the } \\
\text { consequences of disturbances in } \\
\text { energy and amino acid metabolism } \\
\text { and in intestinal microflora }\end{array}$ & {$[64]$} \\
\hline Mice & Anatase $\mathrm{TiO}_{2}$ & $62.5,125$ and $250 \mathrm{mg} / \mathrm{kg}$ & 30 days & $\begin{array}{l}\text { An increase in liver ratios and } \\
\text { histopathological changes in the liver }\end{array}$ & {$[56]$} \\
\hline Mice & $\begin{array}{l}\text { Food-grade } \mathrm{TiO}_{2} \text { was } \\
\text { from SENSIENT } \\
\text { COLOURS }\end{array}$ & $5 \mathrm{mg} / \mathrm{kg}$ & $5 \mathrm{~s}$ & $\begin{array}{l}\mathrm{TiO}_{2} \text { NPs can contribute to } \\
\text { intensification of an existing } \\
\text { intestinal cancer (colon cancer) }\end{array}$ & [69] \\
\hline
\end{tabular}


blood serum: ALT/AST, LDH (alkaline phosphatase (ALT); aspartate aminotransferase (AST); lactate dehydrogenase $(\mathrm{LDH})$, which suggested liver damage after exposure to $\mathrm{TiO}_{2}$ NPs. In addition, nephrotoxicity and pathological renal lesions could be observed in experimental groups. Rats receiving nanoparticles 25 and $80 \mathrm{~nm}$ in size showed a considerable change in the activity of LDH and $\alpha-\mathrm{HBDH}$ in blood serum compared to the control group, which suggested cardiac muscle damage. No pathological lesions were found in the heart, lung, testicle (or ovary) and splenic tissues.

$\mathrm{Bu}$ et al. [64] observed that daily oral administration of $\mathrm{TiO}_{2} \mathrm{NPs}(160,400$ and $1000 \mathrm{mg} / \mathrm{kg})$ to rats over 14 days led to disturbances in energy and amino acid metabolism and in intestinal microflora. They suggested it could cause slight damage to the liver and the heart. Comparative tests of $\mathrm{TiO}_{2}$ NPs toxicity after 30 days of oral exposure $(0,10,50$, $200 \mathrm{mg} / \mathrm{kg} \mathrm{BW} /$ day) to 3-week-old (adolescent) and 8week-old (adult) rats revealed decreased activity of $\mathrm{HBDH}$ and $\mathrm{CK}$ in young rats, which points to potential damage of the cardiac muscle [44] Hong et al. [75] in their studies involving mice showed that 6 months of exposure to $\mathrm{TiO}_{2} \mathrm{NPs}$ $(1.25,2.5$ and $5 \mathrm{mg} / \mathrm{kg})$ caused damage to the cardiac muscle and pneumonia, which could be a result of disturbed expression of cytokines connected with Th1 or Th2 in the heart of mice. Table 2 summarises the effect of $\mathrm{TiO}_{2} \mathrm{NPs}$ exposure.

\section{Nervous System. The Brain}

Nanoparticles, due to their small size, are able to cross the blood-brain barrier (BBB). When inhaled, they accumulate in three different regions of the respiratory tract: the nose and pharynx, trachea and teeth and lung alveoli. From there, through sensory nerves $[76,77]$, they are accumulated mainly in the areas of the brain such as the olfactory bulb and the hippocampus $[3,78,38]$.

In the brain, $\mathrm{TiO}_{2} \mathrm{NPs}$ can cause protein oxidation, oxidative damage $[3,79,29]$ and impairment of antioxidative capacity and increased production of reactive oxygen species (ROS). Other findings include shrinkage of nuclear envelopes [38], apoptosis [33], changes in the content of microelements and macroelements, i.e. copper $(\mathrm{Cu})$, potassium $(\mathrm{K})$ and zinc (Zn) [80], and upset the BBB [81]. According to test results, oxidative stress (OS), apoptosis and the inflammatory response are the main mechanisms underlying the neurotoxicity of metallic nanoparticles [42]. Test results show that antioxidants can reverse neurotoxicity of metallic NPs by decreasing the production of ROS, increasing the activity of antioxidative enzymes, inhibiting the inflammatory condition and reducing the share of apoptotic cells [42].

Many studies revealed a toxic effect of $\mathrm{TiO}_{2}$ NPs depending on the duration of exposure and the dose of NPs. Some authors $[76,82]$ observed this relationship in cultured murine microglia $\mathrm{N} 9$ cells. They found that $\mathrm{TiO}_{2} \mathrm{NPs}$ could elicit apoptosis of $\mathrm{N} 9$ cells in vitro, and thus present a potential risk for the central nervous system (CNS). Ze et al. [83] over 90 days administered $\mathrm{TiO}_{2}$ NPs to mice at three doses and found that NPs could translocate and accumulate in the brain. They demonstrated that the levels of the superoxide $\left(\mathrm{O}^{-}\right)$, $\mathrm{H}_{2} \mathrm{O}_{2}$, carbonyl protein, 8-hydroxy-2'-deoxyguanosine and malondialdehyde (MDA) in the brain of mice were increased in all groups compared to the control group. In addition, changes were identified in the expression of genes associated with OS in the brain of mice. Long et al. [84] observed that

Table 2 The effect of exposure to $\mathrm{NPsTiO}_{2}$ on the cardiovascular system

\begin{tabular}{|c|c|c|c|c|c|}
\hline Model & Type $\mathrm{NPsTiO}_{2}$ & Dose & Exposure time & Effect & References \\
\hline Rats & Anatase $\mathrm{TiO}_{2}$ & $0,2,10,50 \mathrm{mg} / \mathrm{kg}$ & 30 and 90 days & $\begin{array}{l}\text { Heart arrhythmia manifested in reduced activity of } \\
\text { LDH, HBDH and CK, changes in heart rate and } \\
\text { blood pressure }\end{array}$ & {$[20]$} \\
\hline Rats & $\begin{array}{l}\text { Mixture of anatase } \\
\text { and rutile }\end{array}$ & $2 \mathrm{mg} / \mathrm{kg}$ & $4 \mathrm{~h}$ & Increased the rate of cardiac conduction, arrhythmia & {$[73]$} \\
\hline Rats & Rutile $\mathrm{UFTiO}_{2}$ & Areozol $6 \mathrm{mg} / \mathrm{m}^{3}$ & $4 \mathrm{~h}$ & Increased heart rate, increased diastolic blood pressure & {$[74]$} \\
\hline Mice & Unknown & $5 \mathrm{~g} / \mathrm{kg}$ & 14 days & $\begin{array}{l}\text { Considerable change in the activity of LDH and } \\
\text { alpha-HBDH in blood serum, which suggested car- } \\
\text { diac muscle damage. No pathological lesions were } \\
\text { found in the heart, lung, testicle (or ovary) and } \\
\text { splenic tissue }\end{array}$ & {$[45]$} \\
\hline Rats & Unknown & 160,400 and $1000 \mathrm{mg} / \mathrm{kg}$ & 14 days & $\begin{array}{l}\text { Disturbances in energy and amino acid metabolism and } \\
\text { in intestinal microflora. It could cause slight damage } \\
\text { to the liver and the heart }\end{array}$ & {$[64]$} \\
\hline Rats & Anatase $\mathrm{TiO}_{2}$ & $0,10,50,200 \mathrm{mg} / \mathrm{kg}$ & 30 days & $\begin{array}{l}\text { Decreased activity of HBDH (hydroxybutyrate } \\
\text { dehydrogenase) and CK (creatine kinase), damage } \\
\text { of the cardiac muscle }\end{array}$ & {$[44]$} \\
\hline Mice & Anatase $\mathrm{TiO}_{2}$ & $1.25,2.5$ and $5 \mathrm{mg} / \mathrm{kg}$ & Half a year & Damage to the cardiac muscle & {$[75]$} \\
\hline
\end{tabular}

$C K$ creatine kinase, $L D H$ lactate dehydrogenase, $\alpha-H B D H$ alpha-hydroxybutyrate dehydrogenase), $H B D H$ hydroxybutyrate dehydrogenase 
$\mathrm{TiO}_{2}$ NPs stimulated brain microglia to produce ROS and disturbed the production of mitochondrial energy. HuertaGarcía et al. [85], in their studies, found that $\mathrm{TiO}_{2} \mathrm{NPs}$ had a toxic effect on the glial cells (C6 and U373P) of rats and humans. Nanoparticles induced morphological changes, damage to mitochondria and increased the mitochondrial membrane potential (MMP). Other researchers [86] after exposure to $\mathrm{TiO}_{2}$ NPs also observed a decrease in the mitochondrial membrane potential and the levels of nicotinamide adenine dinucleotide (NADH), the mitochondrial function and the production of ROS during mitochondrial respiration in rat tissues.

Márquez-Ramírez et al. [33] evaluated the effect of $\mathrm{TiO}_{2}$ NPs on the glial cells of humans (U373) and rats (C6). They found that, after $96 \mathrm{~h}$ of exposure, $\mathrm{TiO}_{2} \mathrm{NPs}$ had a toxic effect on glial cells by inducing their apoptosis, which suggests that exposure to NPs can lead to brain damage. The study by Coccini et al. [36] showed that $\mathrm{TiO}_{2} \mathrm{NPs}$ had a neurotoxic effect on human brain lines SH-SY5Y and D384. Both after short-term (acute) exposure $(4,24,48 \mathrm{~h} ; 1.5-250 \mu \mathrm{g} / \mathrm{ml})$ and long-term exposure (7-10 days; from 0.05 to $31 \mu \mathrm{g} / \mathrm{ml}$ ) to $\mathrm{TiO}_{2}$ NPs, a toxic effect on the studied cell cultures was observed regardless of the dosage.

$\mathrm{Wu}$ et al. [87] investigated the cytotoxicity of $\mathrm{TiO}_{2}$ NPs by means of PC12 cells (cells used as a model of dopaminergic neurons in vitro for the purposes of studies on neurodegenerative diseases). They observed apoptosis and inhibited cell cycle in PC12 cells after exposure to $\mathrm{TiO}_{2}$ NPs. They also noticed that nanoparticles were more toxic than micrometre particles and that anatase was more toxic than rutile. Sheng et al. [88] showed that $\mathrm{TiO}_{2}$ NPs had a cytotoxic effect on primary hippocampal neurons in 1-day-old foetal rats. Other authors [89] found that exposure to $\mathrm{TiO}_{2} \mathrm{NPs}$ at two doses $(0.25$, $0.5 \mathrm{mg} / \mathrm{ml}$ ) over $24 \mathrm{~h}$ resulted in decreased cell viability, increased release of lactate dehydrogenase and apoptosis. It was also demonstrated that the rate of apoptosis of neurons varied depending on the dose. In addition, $\mathrm{TiO}_{2}$ NPs led to an increase in $\left[\mathrm{Ca}^{2}{ }^{+}\right]$and a reduction in MMP. Those studies suggest that the apoptosis of hippocampal neurons triggered by $\mathrm{TiO}_{2} \mathrm{NPs}$ could be associated with the mitochondria and the signalling pathway. The authors suggest that $\mathrm{TiO}_{2} \mathrm{NPs}$ contributed to a considerable increase in cytotoxicity to $\mathrm{PC} 12$ cells by inducing microglial activation.

In their works, the authors emphasise the potential effect of NPs on neurodegenerative diseases. Hu et al. [90], using the example of embryos of zebrafish (Danio rerio) and $\mathrm{PC} 12$ cell cultures, investigated the neurotoxicity of titanium dioxide nanoparticles. They demonstrated that exposure to $\mathrm{TiO}_{2}$ NPs had an effect on the development of Parkinson's disease (PD). The results indicated that exposure to $\mathrm{TiO}_{2}$ NPs could lead to their accumulation in the brain of zebrafish larvae. An increase in the expression of genes (PINK1, parkin, $\alpha$-syn and UCHL1) associated with the formation of Lewy bodies was observed. In addition, a loss of dopaminergic neurons could be noted, which is one of the characteristic features of PD. Researchers [38] demonstrated that $\mathrm{TiO}_{2}$ NPs accumulated in the murine hippocampus, which led to apoptosis in the hippocampus and induced impairment of spatial memory in mice. Mohammadipour et al. [91] found that after pregnant rats were administered $\mathrm{TiO}_{2}$ NPs $(100 \mathrm{mg} / \mathrm{kg}$ bw), their offspring showed decreased proliferation of hippocampal cells and impaired spatial memory. Moreover, both the Morris water maze test and the passive avoidance test revealed that exposure to $\mathrm{TiO}_{2} \mathrm{NPs}$ considerably distorted the inhibition and learning ability in the offspring. Jeon [92], to enhance the understanding of the molecular mechanism at protein level, carried out a proteomic analysis of protein in the brain of mice. In 11 out of 990 analysed proteins, the level of expression changed more than twice after exposure to $\mathrm{TiO}_{2} \mathrm{NPs}$ : eight proteins had higher and three lower expression after exposure to $\mathrm{TiO}_{2}$ NPs. Moreover, the activity of several antioxidative enzymes and acetylcholine esterase in the brain was reduced. A reduction in the activity of acetylcholine esterase can suggest an increase in cholinergic activity by raising the level of acetylcholine, which is significant for the treatment of Alzheimer's disease [93]. $\mathrm{Hu}$ et al. [94] in their studies also observed that the activity of acetylcholine esterase was inhibited after intragastric administration of $\mathrm{TiO}_{2} \mathrm{NPs}$ to mice (over 60 days). In addition, they demonstrated a decrease in neurobehavioural and morphological capacity and brain damage symptoms in the $\mathrm{Y}$ maze test on mice. They also found inhibited activity of $\mathrm{Na}\left({ }^{+}\right) / \mathrm{K}\left({ }^{+}\right)$- ATPase, $\mathrm{Ca}\left({ }^{2+}\right)$ ATPase, $\mathrm{Ca}\left({ }^{2+}\right) / \mathrm{Mg}\left({ }^{2+}\right)$ - ATPase, acetylcholine esterase, impaired function of the central cholinergic system, considerable reduction in the level of monoamine neurotransmitters (norepinephrine, dopamine and its metabolite 3,4dihydroxyphenylacetic acid, 5-hydroxytryptamine and its metabolite 5-hydroxyindoleacetic acid) and an increased content of acetylcholine, glutamate and nitric oxide. Table 3 summarises the effect of $\mathrm{TiO}_{2} \mathrm{NPs}$ exposure.

\section{Conclusions}

Along with global economic growth, our direct or indirect exposure to metallic nanoparticles has been increasing. With regard to new properties offered by their small size, nanoparticles (NPs) are incorporated in more and more commercial products. Regular supply of $\mathrm{TiO}_{2} \mathrm{NPs}$ at small doses can affect the intestinal mucosa, the brain, the heart and other internal organs, which can lead to an increased risk of developing many diseases, tumours or progress of existing cancer 


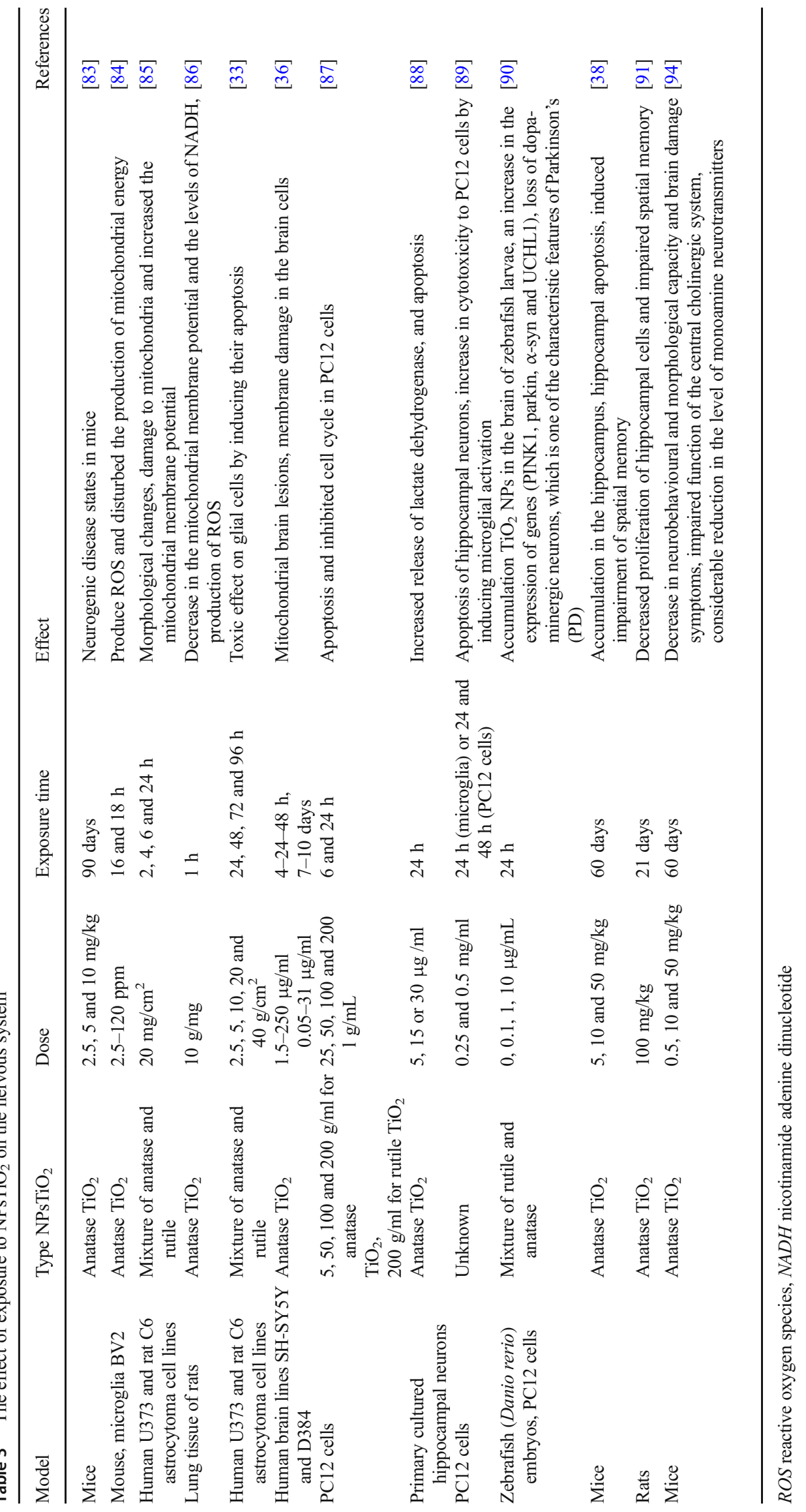


processes. The mechanism behind the nanotoxicity of NPs has not been discovered yet. Many studies attribute it to oxidative stress, thus nanotoxicity is still an important area for future exploration.

\section{Compliance with Ethical Standards}

Conflict of Interest The authors declare that they have any conflicts of interest.

Open Access This article is distributed under the terms of the Creative Commons Attribution 4.0 International License (http:// creativecommons.org/licenses/by/4.0/), which permits unrestricted use, distribution, and reproduction in any medium, provided you give appropriate credit to the original author(s) and the source, provide a link to the Creative Commons license, and indicate if changes were made.

\section{References}

1. Świdwińska-Gajewska AM, Czerczak S (2014) Titanium dioxide nanoparticles-biological effects. Med Pr 65:651-663 https:// www.ncbi.nlm.nih.gov/pubmed/25230569

2. Pandey RK, Prajapati VK (2017) Molecular and immunological toxic effects of nanoparticles. Int J Biol Macromol 107:12781293. https://doi.org/10.1016/j.ijbiomac.2017.09.110

3. Allen R (2016) The cytotoxic and genotoxic potential of titanium dioxide $\left(\mathrm{TiO}_{2}\right)$ nanoparticles on human $\mathrm{SH}-\mathrm{SY} 5 \mathrm{Y}$ neuronal cells in vitro. The Plymouth Student Scientist 9:5-28 http://bcur.org/ journals/index.php/TPSS/article/view/575

4. Samat MH, Ali AMM, Taib MFM, Hassan OH, Yahya MZA (2016) Hubbard U calculations on optical properties of $3 \mathrm{~d}$ transition metal oxide $\mathrm{TiO}_{2}$. Results in Phys 6:891-896. https://oi.org/10. 1016/j.rinp.2016.11.006

5. Bourikas K, Kordulis C, Lycourghiotis A (2014) Titanium dioxide (anatase and rutile): surface chemistry, liquid-solid interface chemistry, and scientific synthesis of supported catalysts. Chem Rev 114: 9754-9823. https://doi.org/10.1021/cr300230q

6. Weir A, Westerhoff P, Fabricius L, Hristovski K, von Goetz N (2012) Titanium dioxide nanoparticles in food and personal care products. Environ Sci Technol 46:2242-2250. https://doi.org/10. 1021/es204168d

7. Hong F, Yu X, Wu N, Yu-Qing Zhang YQ (2017) Progress of in vivo studies on the systemic toxicities induced by titanium dioxide nanoparticles. Toxicol Res 6:115-133. https://doi.org/10.1039/ c6tx00338a

8. Shi H, Magaye R, Castranova V, Zhao J (2013) Titanium dioxide nanoparticles: a review of current toxicological data. Part Fibre Toxicol 10:15. https://doi.org/10.1186/1743-8977-10-15

9. Lim JH, Sisco P, Mudalige TK, Sánchez-Pomales G, Howard PC, Linder SW (2015) Detection and characterization of $\mathrm{SiO}_{2}$ and $\mathrm{TiO}_{2}$ nanostructures in dietary supplements. J Agric Food Chem 63: 3144-3152. https://doi.org/10.1021/acs.jafc.5b00392

10. Rai M, Ribeiro C, Mattoso L, Duran N (2015) Nanotechnologies in food and agriculture. Springer International Publishing Switzerland, pp 352. https://www.springer.com/kr/book/ 9783319140230

11. Heringa MB, Geraets L, van Eijkeren JC, Vandebriel RJ, de Jong WH, Oomen AG (2016) Risk assessment of titanium dioxide nanoparticles via oral exposure, including toxicokinetic considerations. Nanotoxicology 11:1-11. https://doi.org/10.1080/17435390.2016. 1238113
12. Jovanovič B, Cvetkovič VJ, Mitrovič TL (2016) Effects of human food grade titanium dioxide nanoparticle dietary exposure on Drosophila melanogaster survival, fecundity, pupation and expression of antioxidant genes. Chemosphere 144:43-49. https://doi.org/ 10.1016/j.chemosphere.2015.08.054

13. Lu Z, Xie X, Zhou Y, Yu D, Deng Y, Ouyang J, Yang B, Luo D, Zhang D, Kuang H (2018) Gestational exposure to titanium dioxide nanoparticles impairs the placentation through dysregulation of vascularization, proliferation and apoptosis in mice. Int $\mathrm{J}$ Nanomedicine 13:777-789. https://doi.org/10.2147/IJN.S152400

14. Sadeghi R, Rodriquez RJ, Yao Y, Kokini JL (2017) Advances in nanotechnology as they pertain to food and agriculture: benefits and risks. Annu Rev Food Sci Technol 8:467-492. https://doi.org/10. 1146/annurev-food-041715-033338

15. Singh PK, Jairath G, Ahlawat SS (2016) Nanotechnology: a future tool to improve quality and safety in meat industry. J Food Sci Technol 53:1739-1749. https://doi.org/10.1007/s13197-015-2090-y

16. Venkatasubbu GD, Ramasamy S, Pramod Reddy G, Kumar J (2015) Acute and sub-chronic toxicity analysis of surface modified paclitaxel attached hydroxyapatite and titanium dioxide nanoparticles. Int J Nanomedicine 10:137-148. https://doi.org/10.2147/IJN. S79991

17. Rhim JW, Park HM, Ha CS (2013) Bio-nanocomposites for food packaging applications. Prog Polym Sci 38:1629-1652. https://doi. org/10.1016/j.progpolymsci.2013.05.008

18. Vance ME, Kuiken T, Vejerano EP, McGinnis SP, Hochella MF Jr, Rejeski D, Hull MS (2015) Nanotechnology in the real world: redeveloping the nanomaterial consumer products inventory. Beilstein J Nanotechnol 6:1769-1780. https://doi.org/10.3762/ bjnano.6.181

19. CPI (2014) An inventory of nanotechnology-based consumer products introduced on the market. http://www.nanotechproject.org/cpi/ about/analysis/

20. Chen Z, Wang Y, Zhuo L, Chen S, Zhao L, Luan X, Wang H, Jia G (2015) Effect of titanium dioxide nanoparticles on the cardiovascular system after oral administration. Toxicol Lett 239:123-130. https://doi.org/10.1016/j.toxlet.2015.09.013

21. Faust JJ, Doudrick K, Yang Y, Westerhoff P, Capco DG (2014) Food grade titanium dioxide disrupts intestinal brush border microvilli in vitro independent of sedimentation. Cell Biol Toxicol 30: 169-188. https://doi.org/10.1007/s10565-014-9278-1

22. US Food and Drug Administration (2005) Titanium dioxide. USFDA, Washington (DC). Code of Federal Regulations, Title 21, Section 73.575. Available from: http://www.accessdata.fda. gov/scripts/cdrh/cfdocs/cfCFR/CFRSearch.cfm?fr0.2573.575.

23. Dudefoi W, Moniz K, Allen-Vercoe E, Ropers M-H, Virginia K (2017) Impact of food grade and nano-TiO2 particles on a human intestinal community. Food Chem Toxicol 106:242-249. https:// doi.org/10.1016/j.fct.2017.05.050

24. EFSA ANS Panel (2016). Scientific opinion on the re-evaluation of titanium dioxide (E 171) as a food additive. EFSA J. 14:4545 (83 pp.). https://doi.org/10.2903/j.efsa.2016.4545

25. Bachler G, von Goetz N, Hungerbuhler K (2015) Using physiologically based pharmacokinetic (PBPK) modeling for dietary risk assessment of titanium dioxide $\left(\mathrm{TiO}_{2}\right)$ nanoparticles. Nanotoxicology 9:373-380. https://doi.org/10.3109/17435390. 2014.940404

26. Chen XX, Cheng B, Yang YX, Cao A, Liu JH, Du LJ, Liu Y, Zhao Y, Wang H (2013) Characterization and preliminary toxicity assay of nano-titanium dioxide additive in sugar-coated chewing gum. Small 9:1765-1774. https://doi.org/10.1002/smll.201201506

27. Peters RJ, van Bemmel G, Herrera-Rivera Z, Helsper HP, Marvin HJ, Weigel S, Tromp PC, Oomen AG, Rietveld AG, Bouwmeester $\mathrm{H}$ (2014) Characterization of titanium dioxide nanoparticles in food products: analytical methods to define nanoparticles. J Agric Food Chem 62:6285-6293. https://doi.org/10.1021/jf5011885 
28. IARC (2010) carbon black, titanium dioxide, and talc. IARC monographs on the evaluation of carcinogenic risks to humans, Lyon, France. https://monographs.iarc.fr/wp-content/uploads/2018/06/ mono93.pdf

29. Wang J, Liu Y, Jiao F, Lao F, Li W, Gu Y, Li Y, Ge C, Zhou G, Li B, Zhao Y, Chai Z, Chen C (2008) Time-dependant translocation and potential impairment on central nervous system by intranasally instilled $\mathrm{TiO}_{2}$ nanoparticles. Toxicology 254:82-90. https://doi. org/10.1016/j.tox.2008.09.014

30. Baan R, Straif K, Grosse Y, Secretan B, El Ghissassi F, Cogliano V (2006) Carcinogenicity of carbon black, titanium dioxide, and talc. Lancet Oncol 7:295-296

31. Shin SW, Song IH, Um SH (2015) Role of physicochemical properties in panoparticle toxicity. Nanomaterials 5:1351-1365. https:// doi.org/10.1016/S1470-2045(06)70651-9

32. Jugan ML, Barillet S, Simon-Deckers A, Herlin-Boime N, Sauvaigo S, Douki T, Carriere M (2012) Titanium dioxide nanoparticles exhibit genotoxicity and impair DNA repair activity in A549 cells. Nanotoxicology 6:501-513. https://doi.org/10.3109/ 17435390.2011.587903

33. Márquez-Ramírez SG, Delgado-Buenrostro NL, Chirino YI, Iglesias GG, López-Marure R (2012) Titanium dioxide nanoparticles inhibit proliferation and induce morphological changes and apoptosis in glial cells. Toxicology 302:146-156. https://doi.org/ 10.1016/j.tox.2012.09.005

34. Liu R, Zhang X, Pu Y, Yin L, Li Y, Zhang X, Liang G, Li X, Zhang J (2010) Small-sized titanium dioxide nanoparticles mediate immune toxicity in rat pulmonary alveolar macrophages in vivo. $\mathrm{J}$ Nanosci Nanotechnol 10:5161-5169. https://doi.org/10.1166/jnn. 2010.2420

35. Acar MS, Bulut ZB, Ates A, Nami B, Koçak N, Yildiz B (2015) Titanium dioxide nanoparticles induce cytotoxicity and reduce mitotic index in human amniotic fluid-derived cells. Hum Exp Toxicol 34:174-182. https://doi.org/10.1177/0960327114530742

36. Coccini T, Grandi S, Lonati D, Locatelli C, De Simone U (2015) Comparative cellular toxicity of titanium dioxide nanoparticles on human astrocyte and neuronal cells after acute and prolonged exposure. Neurobehav Toxicol 48:77-89. https://doi.org/10.1016/j. neuro.2015.03.006

37. Valdiglesias V, Costa C, Sharma V, Kilic G, Pásaro E, Teixeira JP, Dhawan A, Laffon B (2013) Comparative study on effects of two different types of titanium dioxide nanoparticles on human neuronal cells. Food Chem Toxicol 57:352-361. https://doi.org/10.1016/j. fct.2013.04.010

38. Hu R, Zheng L, Zhang T, Gao G, Cui Y, Cheng Z, Cheng J, Hong M, Tang M, Hong F (2011) Molecular mechanism of hippocampal apoptosis of mice following exposure to titanium dioxide nanoparticles. J Hazard Mater 191:32-40. https://doi.org/10.1016/j. jhazmat.2011.04.027

39. Petković J, Žegura B, Stevanović M (2011) DNA damage and alteration in expression of DNA damage responsive genes induced by $\mathrm{TiO}_{2}$ nanoparticles in human hepatoma HepG2 cells. Nanotoxicology 5:341-353. https://doi.org/10.3109/17435390. 2010.507316

40. Shukla RK, Sharma V, Pandey AK, Singh S, Sultana A, Dhawan A (2011) ROS-mediated genotoxicity induced by titanium dioxide nanoparticles in human epidermal cells. Toxicol in Vitro 25:231241. https://doi.org/10.1016/j.tiv.2010.11.008

41. Bahadar H, Maqbool F, Niaz K, Abdollahi M (2016) Toxicity of nanoparticles and an overview of current experimental models. Iran Biomed J 20:1-11. https://doi.org/10.7508/ibj.2016.01.001

42. Song B, Zhang Y, Liu J, Feng X, Zhou T, Shao L (2016) Is neurotoxicity of metallic nanoparticles the cascades of oxidative stress? Nanoscale Res Lett 11:291. https://doi.org/10.1186/s11671-016$1508-4$
43. Faddah LM, Abdel Baky NA, Al-Rasheed NM, Al-Rasheed NM (2013) Full lengthbresearch Paper: biochemical responses of nanosize titanium dioxide in thebheart of rats following administration of idepenone and quercetin. AJPP 7:2639-2651. https://doi. org/10.5897/AJPP2013.3426

44. Wang Y, Chen Z, Ba T, Pu J, Chen T, Song Y, Gu Y, Qian Q, Xu Y, Xiang K, Wang H, Jia G (2013) Susceptibility of young and adult rats to the oral toxicity of titanium dioxide nanoparticles. Small 9: 1742-1752. https://doi.org/10.1002/smll.201201185

45. Wang J, Zhou G, Chen C, Yu H, Wang T, Ma Y, Jia G, Gao Y, Li B, Sun J, Li Y, Jiao F, Zhao Y, Chai Z (2007) Acute toxicity and biodistribution of different sized titanium dioxide particles in mice after oral administration. Toxicol Lett 168:176-185. https://doi.org/ 10.1016/j.toxlet.2006.12.001

46. McClements DJ, Xiao H, Demokritou P (2017) Physicochemical and colloidal aspects of food matrix effects on gastrointestinal fate of ingested inorganic nanoparticles. Adv Colloid Interf Sci 246: 165-180. https://doi.org/10.1016/j.cis.2017.05.010

47. McClements DJ, DeLoid G, Pyrgiotakis G, Shatkin JA, Xiao H, Demokritou P (2016) The role of the food matrix and gastrointestinal tract in the assessment of biological properties of ingested engineered nanomaterials (iENMs): state of the science and knowledge gaps. NanoImpact 3:47-57. https://doi.org/10.1016/j.impact. 2016.10.002

48. Rahaman T, Vasiljevic T, Ramchandran L (2016) Effect of processing on conformational changes of food proteins related to allergenicity. Trends Food Sci Technol 49:24-34. https://doi.org/10.1016/ j.tifs.2016.01.001

49. Warheit DB, Donner EM (2015) Risk assessment strategies for nanoscale and fine-sized titanium dioxide particles: recognizing hazard and exposure issues. Food Chem Toxicol 85:138-147. https://doi.org/10.1016/j.fct.2015.07.001

50. Xiong S, George S, Yu H, Damoiseaux R, France B, Ng KW, Loo JSC (2013) Size influences the cytotoxicity of poly (lactic-coglycolic acid)(PLGA) and titanium dioxide $\left(\mathrm{TiO}_{2}\right)$ nanoparticles. Arch Toxicol 87:1075-1086. https://doi.org/10.1007/s00204-0120938-8

51. Jones K, Morton J, Smith I, Jurkschat K, Harding AH, Evans G (2015) Human in vivo and in vitro studies on gastrointestinal absorption of titanium dioxide nanoparticles. Toxicol Lett 233:95101. https://doi.org/10.1016/j.toxlet.2014.12.005

52. Geraets L, Oomen AG, Krystek P, Jacobsen NR, Wallin H, Laurentie M, Verharen HW, Brandon EFA, de Jong WH (2014) Tissue distribution and elimination after oral and intravenous administration of different titanium dioxide nanoparticles in rats. Part Fibre Toxicol 11:30. https://doi.org/10.1186/1743-8977-11-30

53. Cho WS, Kang BC, Lee JK, Jeong J, Che JH, Seok SH (2013) Comparative absorption, distribution, and excretion of titanium dioxide and zinc oxide nanoparticles after repeated oral administration. Part Fibre Toxicol 10:9. https://doi.org/10.1186/1743-8977$10-9$

54. MacNicoll A, Kelly M, Aksoy H, Kramer E, Bouwmeester H, Chaudhry Q (2015) A study of the uptake and biodistribution of nano-titanium dioxide using in vitro and in vivo models of oral intake. J Nanopart Res 17:66. https://doi.org/10.1007/s11051-0152862-3

55. Chen J, Dong X, Zhao J, Tang G (2009) In vivo acute toxicity of titanium dioxide nanoparticles to mice after intraperitioneal injection. J Appl Toxicol 29:330-337. https://doi.org/10.1002/jat.1414

56. Duan Y, Liu J, Ma L, Li N, Liu H, Wang J, Zheng L, Liu C, Wang X, Zhao X, Yan J, Wang S, Wang H, Zhang X, Hong F (2010) Toxicological characteristics of nanoparticulate anatase titanium dioxide in mice. Biomaterials 31:894-899. https://doi.org/10.1016/j. biomaterials.2009.10.003

57. Ammendolia MG, Iosi F, Maranghi F, Tassinari R, Cubadda F, Aureli F, Raggi A, Superti F, Mantovani A, De Berardis B (2017) 
Short-term oral exposure to low doses of nano-sized $\mathrm{TiO}_{2}$ and potential modulatory effects on intestinal cells. Food Chem Toxicol 102:63-75. https://doi.org/10.1016/j.fct.2017.01.031

58. Brun E, Barreau F, Veronesi G, Fayard B, Sorieul S, Chanéac C, Carapito C, Rabilloud T, Mabondzo A, Herlin-Boime N, Carrière M (2014) Titanium dioxide nanoparticle impact and translocation through ex vivo, in vivo and in vitro gut epithelia. Part Fibre Toxicol 11:2-16. https://doi.org/10.1186/1743-8977-11-13

59. Nogueira CM, de Azevedo WM, Dagli ML, Toma SH, Leite AZ, Lordello ML, Nishitokukado I, Ortiz-Agostinho CL, Duarte MI, Ferreira MA, Sipahi A (2012) Titanium dioxide induced inflammation in the small intestine. World J Gastroenterol 18:4729-4735. https://doi.org/10.3748/wjg.v18.i34.4729

60. Guo Z, Martucci NJ, Moreno-Olivas F, Takob E, Mahler GJ (2017) Titanium dioxide nanoparticle ingestion alters nutrient absorption in an in vitro model of the small intestine. NanoImpact 5:70-82. https://doi.org/10.1016/j.impact.2017.01.002

61. Chaudhry Q, Watkins R, Castle L (2010) Nanotechnologies in the food arena: new opportunities, new questions, new concerns. In: Chaudhry Q, Castle L, Watkins R (eds) Nanotechnologies in food. RSC Publishing, United Kingdom, pp 1-17 https://pubs.rsc.org/en/ content/ebook/978-0-85404-169-5

62. Wang J, Li N, Zheng L, Wang S, Wang Y, Zhao X, Duan Y, Cui Y, Zhou M, Cai J (2011) P38-Nrf-2 signaling pathway of oxidative stress in mice caused by nanoparticulate $\mathrm{TiO}_{2}$. Biol Trace Elem Res 140:186-197. https://doi.org/10.1007/s12011-010-8687-0

63. Mohamed HRH (2015) Estimation of $\mathrm{TiO}_{2}$ nanoparticle-induced genotoxicity persistence and possible chronic gastritis-induction in mice. Food Chem Toxicol 83:76-83. https://doi.org/10.1016/j. fct.2015.05.018

64. Bu Q, Yan G, Deng P, Peng F, Lin H, Xu Y, Cao Z, Zhou T, Xue A, Wang Y, Cen X, Zhao YL (2010) NMR-based metabonomic study of the sub-acute toxicity of titanium dioxide nanoparticles in rats after oral administration. Nanotechnology 21:125105. https:/doi. org/10.1088/0957-4484/21/12/125105

65. Kreyling WG, Holzwarth U, Haberl N, Kozempel J, Hirn S, Wenk A et al (2017a) Quantitative biokinetics of titanium dioxide nanoparticles after intravenous injection in rats: Part 1. Nanotoxicology 11:434-442. https://doi.org/10.1080/17435390.2017.1306892

66. Kreyling WG, Holzwarth U, Schleh C, Kozempel J, Wenk A, Haberl N et al (2017b) Quantitative biokinetics of titanium dioxide nanoparticles after oral application in rats: Part 2. Nanotoxicology 11:443-453. https://doi.org/10.1080/17435390.2017.1306893

67. Kreyling WG, Holzwarth U, Haberl N, Kozempel J, Wenk A, Hirn $S$ et al (2017c) Quantitative biokinetics of titanium dioxide nanoparticles after intratracheal instillation in rats: Part 3. Nantoxicology 11:454-464. https://doi.org/10.1080/17435390.2017.1306894

68. Bello D, Warheit DB (2017) Biokinetics of engineered nano- $\mathrm{TiO}_{2}$ in rats administered by different exposure routes: implications for human health. Nanotoxicology 11:431-433. https://doi.org/10. 1080/17435390.2017.1330436

69. Urrutia-Ortega IM, Garduño-Balderas LG, Delgado-Buenrostro NL, Freyre-Fonseca V, Flores-Flores JO, González-Robles A, Pedraza-Chaverri J, Hernández-Pando R, Rodríguez-Sosa M, Leon-Cabrera S, Terrazas LI, van Loveren H, Chirino YI (2016) Food-grade titanium dioxide exposure exacerbates tumor formation in colitis associated cancer model. Food Chem Toxicol 93:20-31. https://doi.org/10.1016/j.fet.2016.04.014

70. Warheit DB, Hoke RA, Finlay C, Donner EM, Reed KL, Sayes CM (2007) Development of a base set of toxicity tests using ultrafine $\mathrm{TiO} 2$ particles as a component of nanoparticle risk management. Toxicol Lett 171:99-110. https://doi.org/10.1016/j.toxlet.2007.04. 008

71. Gui S, Zhang Z, Zheng L, Cui Y, Liu X, Li N, Sang X, Sun Q, Gao G, Cheng Z, Cheng J, Wang L, Tang M, Hong F (2011) Molecular mechanism of kidney injury of mice caused by exposure to titanium dioxide nanoparticles. J Hazard Mater 195:365-370. https://doi. org/10.1016/j.jhazmat.2011.08.055

72. Trouiller B, Reliene R, Westbrook A, Solaimani P, Schiestl RH (2009) Titanium dioxide nanoparticles induce DNA damage and genetic instability in vivo in mice. Cancer Res 69:8784-878969. https://doi.org/10.1158/0008-5472.CAN-09-2496

73. Savi M, Rossi S, Bocchi L, Gennaccaro L, Cacciani F, Perotti A, Amidani D, Alinovi R, Goldoni M, Aliatis I, Lottici PP, Bersani D, Campanini M, Pinelli S, Petyx M, Frati C, Gervasi A, Urbanek K, Quaini F, Buschini A, Stilli D, Rivetti C, Macchi E, Mutti A, Miragoli M, Zaniboni M (2014) Titanium dioxide nanoparticles promote arrhythmias via a direct interaction with rat cardiac tissue. Part Fibre Toxicol 11:63. https://doi.org/10.1186/s12989-0140063-3

74. Kan H, Wu Z, Lin YC, Chen TH, Cumpston JL, Kashon ML, Leonard S, Munson AE, Castranova V (2014) The role of nodose ganglia in the regulation of cardiovascular function following pulmonary exposure to ultrafine titanium dioxide. Nanotoxicology 8: 447-454. https://doi.org/10.3109/17435390.2013.796536

75. Hong FS, Wang L, Yu XH, Zhou YJ, Hong J, Sheng L (2015) Toxicological effect of $\mathrm{TiO} 2$ nanoparticle induced myocarditis in mice. Nanoscale Res Lett 10:326. https://doi.org/10.1186/s11671015-1029-6

76. Czajka M, Sawicki K, Sikorska K, Popek S, Kruszewski M, KapkaSkrzypczak L (2015) Toxicity of titanium dioxide nanoparticles in central nervous system. Toxicol in Vitro 29:1042-1052. https://doi. org/10.1186/s11671-015-1029-6

77. Simkó M, Mattsson MO (2010) Risks from accidental exposures to engineered nanoparticles and neurological health effects: a critical review. Part Fibre Toxicol 7:42. https://doi.org/10.1186/1743-8977$7-42$

78. Bramini M, Ye D, Hallerbach A, Raghnaill MN, Salvati A, Aberg C, Dawson KA (2014) Imaging approach to mechanistic study of nanoparticle interactions with the blood-brain barrier. ACS Nano 8: 4304-4312. https://doi.org/10.1021/nn5018523

79. Feng X, Chen A, Zhang Y, Wang J, Shao L, Wei L (2015) Central nervous system toxicity of metallic nanoparticles. Int $\mathrm{J}$ Nanomedicine 10:4321-4340. https://doi.org/10.2147/IJN.S78308

80. Federici G, Shaw BJ, Handy RD (2007) Toxicity of titanium dioxide nanoparticles to rainbow trout (Oncorhynchus mykiss): gill injury, oxidative stress, and other physiological effects. Aquat Toxicol 84:415-430. https://doi.org/10.1016/j.aquatox.2007.07.009

81. Brun E, Carrière M, Mabondzo A (2012) In vitro evidence of dysregulation of blood-brain barrier function after acute and repeated/ long-term exposure of $\mathrm{TiO}_{2}$ nanoparticles. Biomaterials 33:886896. https://doi.org/10.1016/j.biomaterials.2011.10.025

82. Li XB, Xu SQ, Zhang ZR, Schluesener HJ (2009) Apoptosis induced by titanium dioxide nanoparticles in cultured murine microglia N9 cells. Chin Sci Bull 54:3830-3836. https://doi.org/10.1007/ s11434-009-0548-x

83. Ze Y, Hu R, Wang X, Sang X, Ze X, Li B, Su J, Wang Y, Guan N, Zhao X, Gui S, Zhu L, Cheng Z, Cheng J, Sheng L, Sun Q, Wang L, Hong F (2014) Neurotoxicity and gene-expressed profile in braininjured mice caused by exposure to titanium dioxide nanoparticles. J Biomed Mater Res A 102:470-478. https://doi.org/10.1002/jbm. a. 34705

84. Long TC, Saleh N, Tilton RD, Lowry GV, Veronesi B (2006) Titanium dioxide $(\mathrm{P} 25)$ produces reactive oxygen species in immortalized brain microglia (BV2): implications for nanoparticle neurotoxicity. Environ Sci Technol 40:4346-4352. https://doi.org/ 10.1021/es060589n

85. Huerta-García E, Pérez-Arizti JA, Márquez-Ramírez SG, DelgadoBuenrostro NL, Chirino YI, Iglesias GG, López-Marure R (2014) Titanium dioxide nanoparticles induce strong oxidative stress and mitochondrial damage in glial cells. Free Radic Biol Med 73:84 94. https://doi.org/10.1016/j.freeradbiomed.2014.04.026 
86. Freyre-Fonseca V, Delgado-Buenrostro NL, Gutiérrez-Cirlos EB, Calderón-Torres CM, Cabellos-Avelar T, Sánchez-Pérez Y, Pinzón E, Torres I, Molina-Jijón E, Zazueta C, Pedraza-Chaverri J, GarcíaCuéllar CM, Chirino YI (2011) Titanium dioxide nanoparticles impair lung mitochondrial function. Toxicol Lett 202:111-119. https:// doi.org/10.1016/j.toxlet.2011.01.025

87. Wu J, Sun J, Xue Y (2010) Involvement of JNK and P53 activation in $\mathrm{G} 2 / \mathrm{M}$ cell cycle arrest and apoptosis induced by titanium dioxide nanoparticles in neuron cells. Toxicol Lett 199:269-276. https://doi. org/10.1016/j.toxlet.2010.09.009

88. Sheng L, Ze Y, Wang L, Yu X, Hong J, Zhao X, Ze X, Liu D, Xu B, Zhu Y, Long Y, Lin A, Zhang C, Zhao Y, Hong F (2015) Mechanisms of $\mathrm{TiO}_{2}$ nanoparticle induced neuronal apoptosis in rat primary cultured hippocampal neurons. J Biomed Mater Res A 103:1141-1149. https://doi.org/10.1002/jbm.a.35263

89. Xue Y, Wu J, Sun J (2012) Four types of inorganic nanoparticles stimulate the inflammatory reaction in brain microglia and damage neurons in vitro. Toxicol Lett 214:91-98. https://doi.org/10.1016/j. toxlet.2012.08.009

90. Hu Q, Guo F, Zhao F, Fu Z (2017) Effects of titanium dioxide nanoparticles exposure on parkinsonism in zebrafish larvae and PC12. Chemosphere 173:373-379. https://doi.org/10.1016/j. chemosphere.2017.01.063
91. Mohammadipour A, Fazel A, Haghir H, Motejadej F, Rafatpanah $\mathrm{H}$, Zobihi H, Hosseini H, Bideskan AE (2014) Maternal exposure to titanium dioxide nanoparticles during pregnancy; impaired memory and decreased hippocampal cell proliferation in rat offspring. Environ Toxicol Pharmacol 37:617-625. https://doi.org/10.1016/j. etap.2014.01.014

92. Jeon YM, Park SK, Lee MY (2011) Toxicoproteomic identification of $\mathrm{TiO}_{2}$ nanoparticle-induced protein expression changes in mouse brain animal. Anim Cells Syst 15:107-114. https://doi.org/10.1080/ 19768354.2011.555144

93. Szwajgier D, Borowiec K (2012) Screening for cholinesterase inhibitors in selected fruits and vegetables. Ejpau 15:06 https://www. researchgate.net/publication/267844931_screening_for cholinesterase_inhibitors_in_selected_fruits_and_vegetables

94. Hu R, Gong X, Duan Y, Li N, Che Y, Cui Y, Zhou M, Liu C, Wang H, Hong F (2010) Neurotoxicological effects and the impairment of spatial recognition memory in mice caused by exposure to $\mathrm{TiO} 2$ nanoparticles. Biomaterials 31:8043-8050. https://doi.org/10.1016/ j.biomaterials.2010.07.011

Publisher's Note Springer Nature remains neutral with regard to jurisdictional claims in published maps and institutional affiliations. 